University of Nebraska - Lincoln

DigitalCommons@University of Nebraska - Lincoln

Faculty Publications from the Harold W. Manter Laboratory of Parasitology

1986

\title{
Cysts Resembling Hydatids in a Chicken
}

Gerald D. Schmidt

University of Northern Colorado, nemataslg@gmail.com

Robert L. Rausch

University of Washington, rausch@u.washington.edu

Follow this and additional works at: https://digitalcommons.unl.edu/parasitologyfacpubs

Part of the Parasitology Commons

Schmidt, Gerald D. and Rausch, Robert L., "Cysts Resembling Hydatids in a Chicken" (1986). Faculty Publications from the Harold W. Manter Laboratory of Parasitology. 550.

https://digitalcommons.unl.edu/parasitologyfacpubs/550

This Article is brought to you for free and open access by the Parasitology, Harold W. Manter Laboratory of at DigitalCommons@University of Nebraska - Lincoln. It has been accepted for inclusion in Faculty Publications from the Harold W. Manter Laboratory of Parasitology by an authorized administrator of DigitalCommons@University of Nebraska - Lincoln. 


\title{
Cysts Resembling Hydatids in a Chicken
}

\author{
Gerald D. Schmidt ${ }^{\mathrm{A}}$ and Robert L. Rausch ${ }^{\mathrm{B}}$ \\ ADepartment of Biological Sciences, University of Northern Colorado, Greeley, Colorado 80639 \\ BDivision of Animal Medicine, School of Medicine, University of Washington, \\ Seattle, Washington 98195 \\ Received 5 February 1986
}

\begin{abstract}
SUMMARY. Two large cysts recovered from the abdominal cavity of a domestic chicken superficially resembled hydatid cysts of Echinococcus spp. No protoscolices were present. Microscopic examination of the internal lining of one of the cysts revealed a single cuboidal to columnar, ciliated epithelium, leading to a diagnosis of oviduct cysts. Earlier records of hydatids of fowl are reviewed.
\end{abstract}

RESUMEN. Reporte de Caso-Quistes en un pollo semejantes a la hidatidosis.

Se encontraron dos quistes grandes en la cavidad abdominal de un pollo doméstico. Superficialmente los quistes parecian quistes hidatídicos de Echinococcus spp. No se encontraron escólecis o cabezas de la tenia. El examen microscópico de la pared interna de uno de los quistes mostró un epitelio ciliado, variando de cuboidal a columnar, conduciendo a un diagnóstico de quiste en el oviducto. Se revisan otros casos de hidatidosis en aves.

Previous reports of hydatid cysts from avian hosts are few $(1,2,3,4)$. These records are old and cite chickens, turkeys, and peafowl as hosts. This

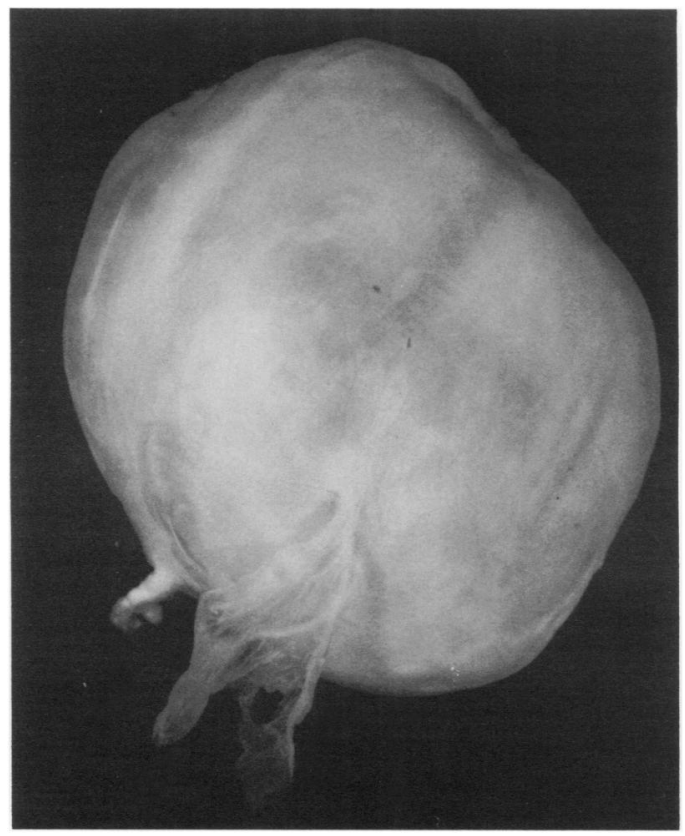

Fig. 1. Entire cyst, $5 \mathrm{~cm}$ greatest width. report describes hydatid cyst-like structures found in a domestic chicken.

\section{CASE REPORT}

During a routine classroom demonstration of avian anatomy, two conspicuous membranous cysts were found in the abdominal cavity of a barred rock hen. The bird had been purchased locally from a farmer near Greeley, Colorado. The larger cyst (Fig. 1) was $5 \mathrm{~cm}$ wide and was pearly white. The smaller cyst was irregular and $2 \mathrm{~cm}$ long. The former was attached by a short stalk to a mesentery, whereas the latter was unattached. Both appeared very much like hydatid cysts. No protoscolices were present, which is typical of hydatids in abnormal hosts.

The smaller cyst was sectioned, stained, and mounted on slides for study by standard technique. Internally it was subdivided into compartments (Fig. 2) somewhat similar to an alveolar hydatid. Close examination of the cyst lining revealed a single cuboidal to columnar ciliated epithelium (Fig. 3), quite unlike that of any species of cestode cyst. This led us to a diagnosis of oviduct cysts.

This finding suggests that earlier reports of hydatid cysts from fowl should be regarded with 


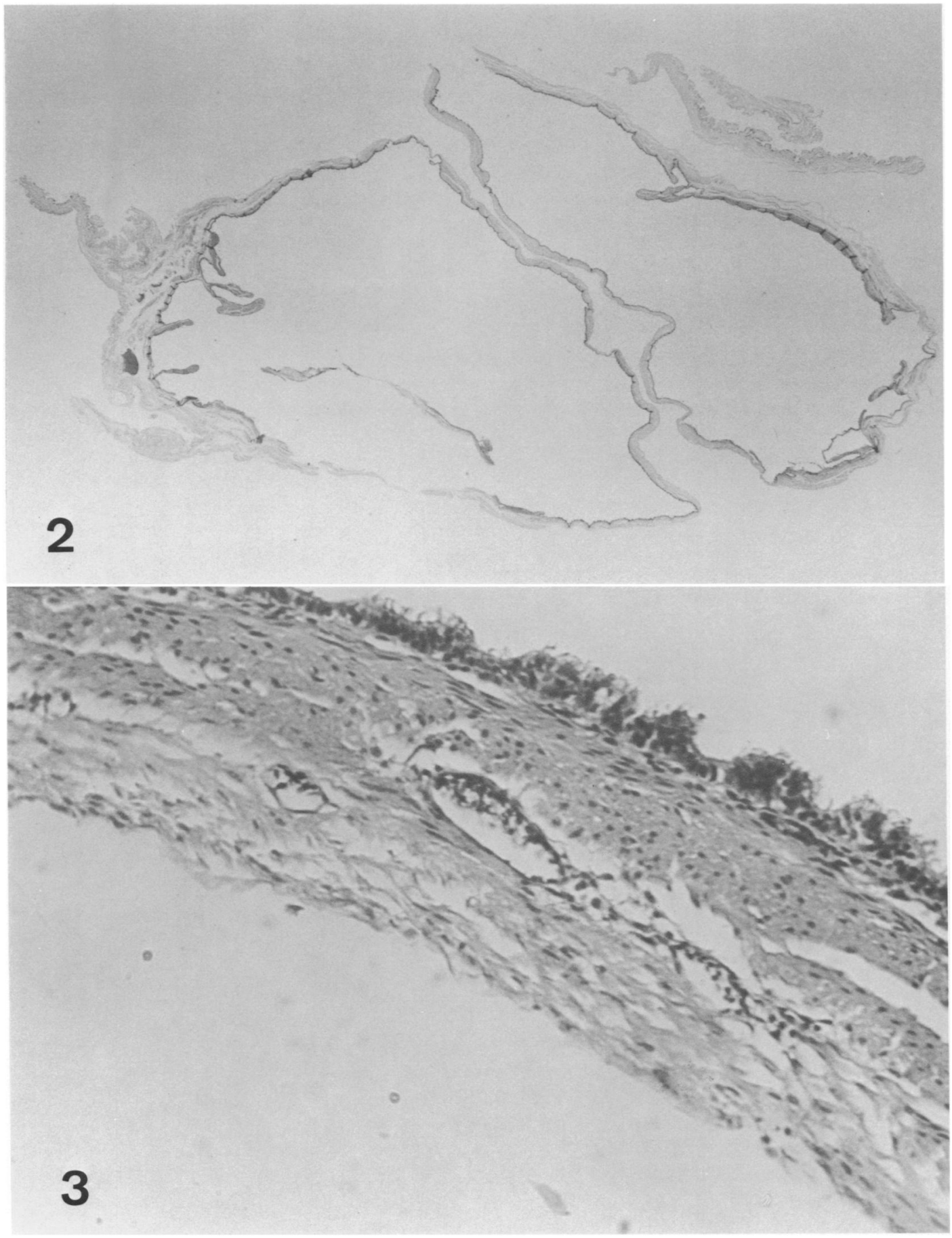

Figs. 2, 3. (2). Cross section of cyst. $8.7 \times$. (3). Lining of cyst, showing ciliated epithelium. $87 \times$. 
caution, as they too may have been oviduct or other cysts.

\section{REFERENCES}

1. Joyeux, C., and J. G. Baer. Cestodes. Faune Fr. 30:1-613. 1936.

2. Leonardi, C. L'echinococco. Cisti d-echinococco del fegato in um tacchino (Meleagris gallopavo). Boll. Nat. Coll. Siena 16:133-134. 1896.

3. Neumann, L. G. Parasites et maladies parasitaires des oiseaux domestiques. Privately published, Paris. pp. 1-230. 1909.
4. Siebold, C. T. E. von. Zur Entwicklungsgeschichte der Helminthen. In: Die Physiologie als Erfahrungswissenschaft, 2nd ed. K. F. Burdach, Leipzig. 2:183-213. 1837.

\section{ACKNOWLEDGMENTS}

Thanks are expressed to Dr. Ronald K. Plakke, University of Northern Colorado, and to Dr. W. E. Giddens, Jr., University of Washington, for assistance. Thanks also to Dr. Warren Buss, who made the photographs. 